\section{Semiología y Fundamentos de la Neurología clínica}

Cuando aparece un nuevo libro que se refiere a temas que son largamente conocidos y centenariamente editados, como lo es el examen neurológico, surge preguntarse que puede haber de novedoso en lo que tal libro dice y muestra, que ya no hayan sido dicho o mostrado. Sin embargo en este caso estoy seguro que el libro "Semiología y Fundamentos de la Neurología Clínica” de profesor Carlos Silva Rosas marcará un hito en la literatura médico- neurológica de nuestro país y seguramente de Latinoamérica por su novedosa presentación y la calidad expositiva del autor.

La enseñanza médica propiamente tal, se inicia habitualmente con el aprendizaje de las destrezas que imparte la semiología y que siempre resultan esenciales. Para los estudiantes, así como para los futuros especialistas, la lectura de los textos de semiología representa el modo de iniciarse en los misterios del examen clínico. El texto del Dr Silva ha logrado exitosamente, con palabras precisas, además de bellas y novedosas imágenes llevarnos a la intimidad mágica de la clínica neurológica. Esta publicación viene a complementar de manera certera los requerimientos indispensables de un adecuado enfoque clínico. El texto va detallando exhaustivamente los caminos que permiten lograr la aproximación justa a la revelación del gran misterio, que siempre es el diagnóstico. El examen del enfermo es la base del quehacer médico desde antes de Hipócrates y para ello se han establecido condiciones metodológicas que en este tratado se ve brillantemente explicitadas

El libro está ordenado en siete capítulos y contiene un ademdum con preguntas muy significativas y pertinentes. Los distintos capítulos son tratados con soltura, asociando buenas imágenes al contexto. En el capitulo primero, referido a la anamnesis, hace relieve la inserción de ejemplos clínicos muy didácticos, ejemplos originales, surgidos de la experiencia del autor y que van variando de acuerdo al tema en los siguientes capítulos. Además, me pareció notable el esfuerzo desarrollado en las ilustraciones del examen motor, que se realza con múltiples y coordinadas fotografías. También destacan los bellos y certeros dibujos que se despliegan en el capítulo de pares craneales.

Llama la atención la permanente preocupación del autor en el logro de un alto nivel didáctico del texto que trasciende durante toda su lectura y consigue que el libro se transforme en un excelente compañero docente. El enfoque dado logra complementar lo semiológico y lo clínico, valorizando el despliegue hecho en el examen motor, sensitivo, de pares craneanos, así como en el capítulo dedicado a la punción lumbar, que no dejan dudas respecto a los modos y objetivos buscados.

En resumen el libro de semiología neurológica del Dr Silva es un libro hermoso y magníficamente editado.

Luis Cartier 